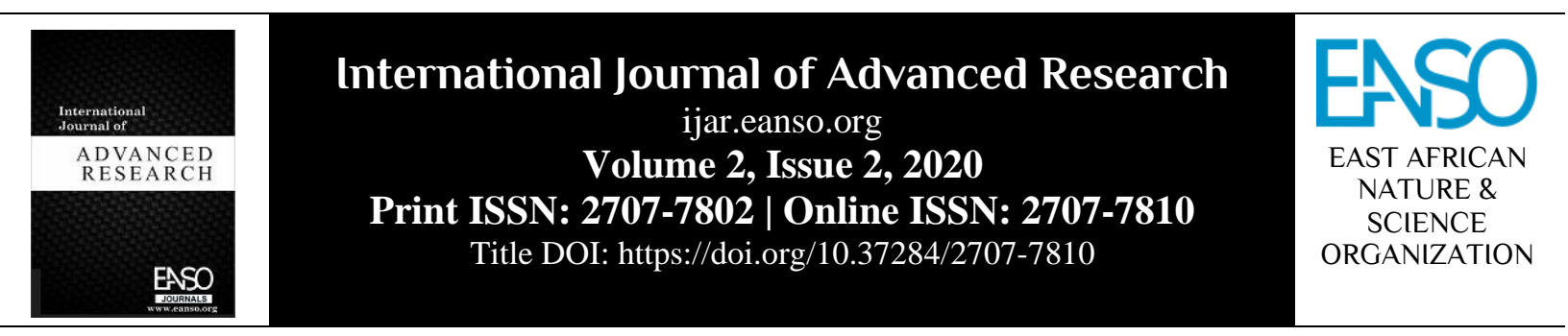

Original Article

\title{
Analysis of Floristic Diversity and Quantification of Diameter Class Aboveground Biomass (AGB) and Carbon Stocks of Afromontane Vegetation of Nkoanenkole Forest Reserve (NCFR) in Northern Tanzania
}

\author{
Canisius J. Kayombo ${ }^{*}$, Simon Lukumay ${ }^{2}$, Henry John Kaguo ${ }^{3}$, \\ Pamela Kessy ${ }^{2}$ \& Victor Kahaya ${ }^{3}$ \\ ${ }^{1}$ Forestry Training Institute, Olmotonyi, P. O. Box 943, Arusha, Tanzania. \\ ${ }^{2}$ Tanzania Forest Service, Usa River, Arusha-Tanzania. \\ ${ }^{3}$ Meru District Council, Tanzania. \\ *Author for Correspondence Email: Kayombo33@yahoo.co.uk or kayombocanisius@gmail.com.
}

Article DOI: https://doi.org/10.37284/ijar.2.2.245

Publication Date: ABSTRACT

07 December 2020 Nkoanenkole Forest Reserve (NCFR) is such a potential area in floristic

Keywords:

Floristic Diversity, Abundance,

Dominance,

Density,

Aboveground Biomass,

Carbon Stocks,

Nkoanenkole Catchment,

Forest Reserve.

diversity within a relatively small area of 370.2 ha. The study was conducted in 2018 to analyze the floristic diversity and quantify the tree species aboveground biomass and carbon stocks of Nkoanenkole Catchment Forest Reserve (NCFR) in Arumeru District, Arusha-Tanzania. Systematic random sampling was applied, whereby a total of 24 plots with a $15 \mathrm{~m}$ radius $(706.5$ $\mathrm{m}^{2}$ ) were set at an inter plot and transect distance of $350 \mathrm{~m}$. The plant species were identified by their botanical names, determined for abundance, and trees with $\geq 5 \mathrm{~cm}$ DBH were measured. Shannon Wiever (H'), and Simpson indices were applied to calculate the index of diversity. Also, density and relative density were calculated. The AGB and AGC mg ha ${ }^{-1}$ were calculated using allometric models. 147 plant species were identified from the 24 sample plots, of which 54 were trees, 31 shrubs and lianas, 48 herbs, 3 sedges, 6 grass species, and 6 belonged to the ferns. The calculate H' was 3.3316 for trees with an index of dominance of 0.053 , and 2.449 for shrubs and lianas, sedges, herbs, and ferns with an index of dominance of 0.00.3135. The families of Euphorbiaceae, Rubiaceae, Fabaceae, and Asteraceae were determined to be the most dominant in terms of the number species. The identified tree seedlings were 14 with an abundance of 136 , the density of $16.513 \pm 0.590$, and a relative density of 20.14 \pm 0.73 . Bersama abyssinica and Psychotria riparia were the most dominant tree seedlings. The DBH-class of $15 \pm 5$ had the highest AGB $(\mathrm{kg})$ and AGC mg ha ${ }^{-1}$, followed by $25 \pm 15$, $55 \pm 45,65 \pm 55$, and the rest. NCFR is latent for its biodiversity, hence recommending further study on biological diversity, the possibility for upgrading the NCFR to the nature reserve, encourage beekeeping as potential 
pollinators, discourage illegal human activities through education and regular patrols.

\section{APA CITATION}

Kayombo, C., Lukumay, S., Kaguo, H., Kessy, P., \& Kahaya, V. (2020). Analysis of Floristic Diversity and Quantification of Diameter Class Aboveground Biomass (AGB) and Carbon Stocks of Afromontane Vegetation of Nkoanenkole Forest Reserve (NCFR) in Northern Tanzania. International Journal of Advanced Research, 2(2), 19-31. https://doi.org/10.37284/ijar.2.2.245

\section{CHICAGO CITATION}

Kayombo, Canisius, Simon Lukumay, Henry Kaguo, Pamela Kessy, and Victor Kahaya. 2020. "Analysis of Floristic Diversity and Quantification of Diameter Class Aboveground Biomass (AGB) and Carbon Stocks of Afromontane Vegetation of Nkoanenkole Forest Reserve (NCFR) in Northern Tanzania”. International Journal of Advanced Research 2 (2), 19-31. https://doi.org/10.37284/ijar.2.2.245.

\section{HARVARD CITATION}

Kayombo, C., Lukumay, S., Kaguo, H., Kessy, P. and Kahaya, V. (2020) “Analysis of Floristic Diversity and Quantification of Diameter Class Aboveground Biomass (AGB) and Carbon Stocks of Afromontane Vegetation of Nkoanenkole Forest Reserve (NCFR) in Northern Tanzania”, International Journal of Advanced Research, 2(2), pp. 19-31. doi: 10.37284/ijar.2.2.245.

\section{IEEE CITATION}

C. Kayombo, S. Lukumay, H. Kaguo, P. Kessy, and V. Kahaya, "Analysis of Floristic Diversity and Quantification of Diameter Class Aboveground Biomass (AGB) and Carbon Stocks of Afromontane Vegetation of Nkoanenkole Forest Reserve (NCFR) in Northern Tanzania”, IJAR, vol. 2, no. 2, pp. 19-31, Nov. 2020.

\section{MLA CITATION}

Kayombo, Canisius, Simon Lukumay, Henry Kaguo, Pamela Kessy, and Victor Kahaya. "Analysis of Floristic Diversity and Quantification of Diameter Class Aboveground Biomass (AGB) and Carbon Stocks of Afromontane Vegetation of Nkoanenkole Forest Reserve (NCFR) in Northern Tanzania". International Journal of Advanced Research, Vol. 2, no. 2, Nov. 2020, pp. 1931, doi:10.37284/ijar.2.2.245.

\section{INTRODUCTION}

It has been stated that globally, 52\% of the total forests are in tropical regions and they are known to be the most important areas in terms of biodiversity. The diversity is an indicator that allows appreciating the links between the richness and the abundance of individual trees (Ifo et al., 2016). Fumilayo (2014) and Ifo et al. (2016) add that tropical forests have been a subject for several studies aimed at providing a better understanding of the role they play in sustainable development, climate change, and floristic biodiversity. Tropical forests provide many goods and ecosystem services such as prevention of soil erosion and preservation of habitats for plants and animals. Tanzania is very rich in natural resources existing in the terrestrial and aquatic ecosystem, including flora and fauna. Tanzania has about 33.5 million hectares of forests and woodlands, making up about $36 \%$ of its total land area (MNRT, 1998). Out of this area, about 13 million hectares have been gazetted as forest reserves; and about 1.6 million hectares are under the water catchment management (MNRT, 1998; URT, 2009).
Catchment forests in Tanzania are mostly tropical moist forests found mainly in mountainous areas (URT, 2002). The water catchment forest is an area surrounding watercourse and providing it with water (FAO, 2011). Tanzania's catchment forests are increasingly becoming important resources in supporting the livelihood of the majority of rural and urban populations as well as conserving potential ecological areas ensuring a sustained supply of water (URT, 2002). The NCFR is a source of water, hence has water catchment value (Kashenge, 1986). The water is piped and distributed to the Usa River Township for domestic use and irrigation farming (Kayombo et al., 2017). Forests have the ecological functions of encouraging rainfall, water catchment, stabilizing water flows, reducing erosion, landslides, and floods in areas of steep topography and high precipitation. They are areas of high biodiversity (Forbes \& Broadhead, 2011). The forests have an important function of supporting large populations downstream with water for irrigation, hydroelectricity and industrial use, but also for livestock among other domestic uses. Forest reserves in Tanzania cover about 36.8\% of the country. However, illegal logging and clearing of 
forest and woodland for farming and charcoal making are accelerating with losses put at over 91,000 hectares per annum. 15\% of Tanzania's forest cover was lost between 1990-2005 (URT, 2002).

\section{Nkoanenkole Catchment Forest Reserve Resources (NCFR) Floristic Diversity Potential}

Nkoanenkole Catchment Forest Reserve (NCFR) has an area of 370.2 ha $\left(3,702,000 \mathrm{~m}^{2}\right)$. It is situated at the foot of Mount Meru and accommodates relatively high biological diversity; its sustainability remains dependent the human conservation efforts. NCFR has a huge potential for water catchment and habitat for wild flora and fauna, as well as maintaining the natural scenery. The sustainability of forest resources is well cared when the contained organisms are systematically being determined for their existence, diversity, abundance and forms (herbs, sedges, shrubs, lianas, trees), and stand density. Stand density is a management tool that helps forest managers to more effectively manage the forests and forest resource determination (Kara, 2018). NCFR plays a role as a carbon sink, protection of soil erosion, windbreak, and regulation of temperature and rainfall, a provision that calls for its sustainability rather than consumption of the resource.

\section{Aboveground Biomass ad Carbon Stocks}

Forest carbon stock is a time-integrated expression of numerous processes ranging from plant growth and mortality to natural disturbance and human land use (Asner et al., 2018). NCFR is among the protected forest with inadequate information on biological diversity, and composition, and aboveground biomass and carbon stocks (AGCmg $\left.\mathrm{ha}^{-1}\right)$ just like in many other countries in the world. National Research Council (2008) stated that the global importance of tropical forests reflects both their enormous biodiversity, which includes a high proportion of endemic species, and their importance to planet earth experiencing the greenhouse effect, as fast sinks for carbon, yet it is remarkable how little we know about their diversity. This study intended to analyse the existing floristic diversity of Nkoanenkole Catchment Forest Reserve (NCFR).

\section{MATERIAL AND METHODS}

\section{Description of Nkoanenkole Catchment Forest Reserve (NCFR)}

The NCFR is located between Latitude of $3^{0} 19^{\prime}$ and $3^{\circ} 20^{\prime}$ South of Equator and between Longitude of $36^{\circ} 50^{\prime}$ and $36^{\circ} 52^{\prime}$ East of Greenwich Meridian (Kayombo et al., 2017). The NCFR is about $3.5 \mathrm{~km}$ North of Usa River Township and $28 \mathrm{~km}$ NorthEast of Arusha City. The altitude ranges from 1300 - $1800 \mathrm{~m}$ above sea level (Kayombo et al., 2017). NCFR lies on the southern foot of Mount Meru in the Arusha National Park (Figure 1). It borders the Meru-Usa Plantation to the north, Nkoanenkole village to the north-west, west and to the south. NCFR border four villages which are Ngongongare to the east, Nkoanenkole to the south, Nkure to the south-west and west, and Kalinga to the west. NCFR covers an area of 370.2 ha $\left(3,702,000 \mathrm{~m}^{2}\right)$. 
Figure 1: Location of Nkoanenkole Catchment Forest Reserve (NCFR)

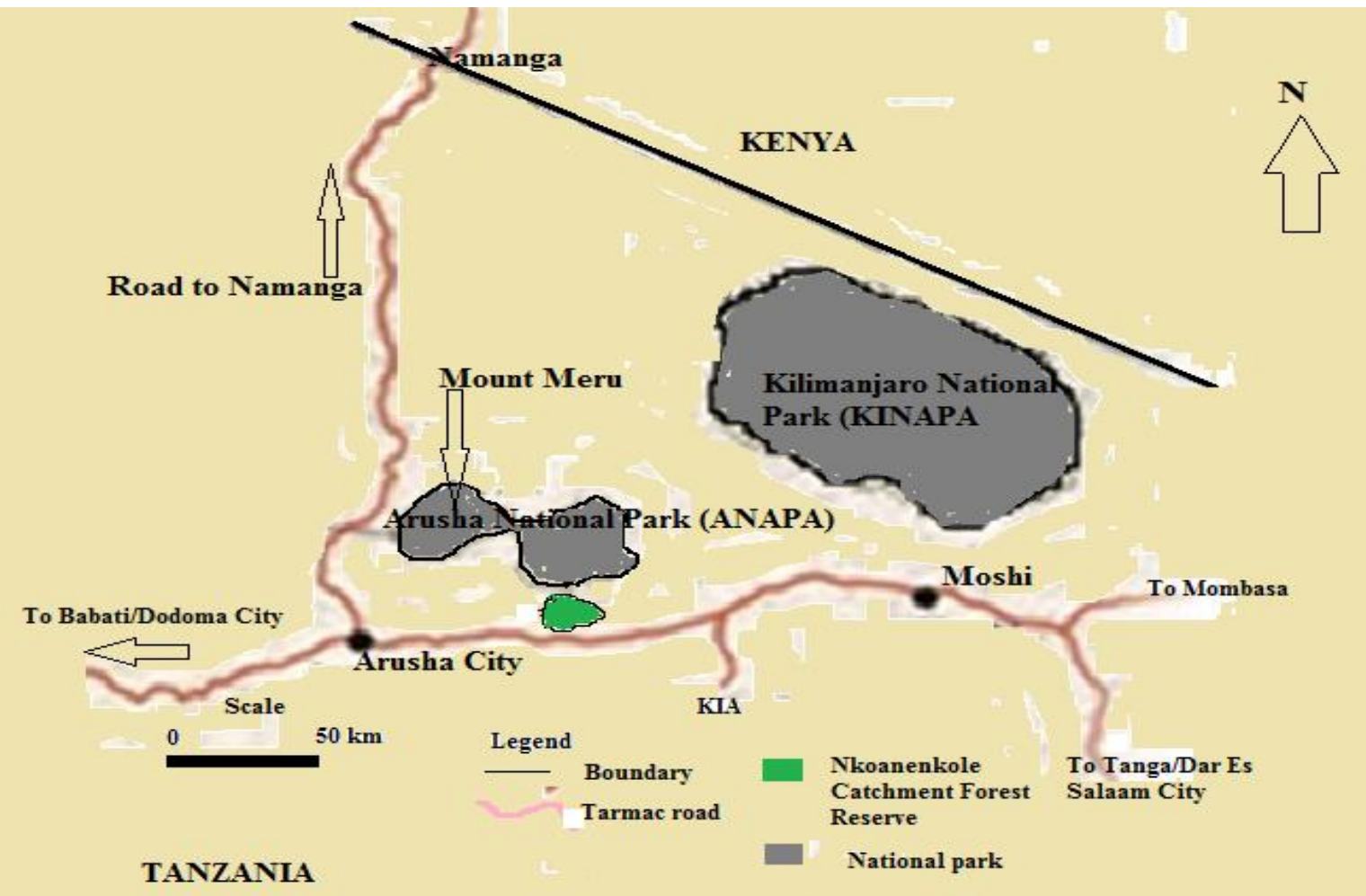

NCFR is underground water sub-Afromontane forest dominated by Celtis africana, Vepris simplicifolia, Tabernaemontana ventricosa, Rauvolfia caffra, Rothmannia urceliformis, Trilepesium madagascariensis, Diospyros usambarensis and Albizia schimperiana to list a few (Kayombo et al., 2017). Apart from being a somewhat homogenous vegetation type, the following vegetation types were described during the survey: moist forest, dry forest, and bushland patches. The moist forest area composed of high canopy coverage and the dominant trees were; Tabernaemontana ventricose, Croton sylvaticus, Ekebergia capensis, Psychotria riparia, Casearia battiscombei, and Trichilia emetica. The dry forest area was occupied by Cordia africana, Euclea divinorum, Celtis Africana, Olea capensis and Diospyros abyssinica. The bushland was dominated by Vernonia myriantha mixed with Caesalpinia decapetala in some parts of NCFR, while some parts were completely dominated by the alien plant, Caesalpinia decapetala, and rarely with Lantana camara.
The NCFR experiences the oceanic rainfall with continental temperatures. Rainfall on the southern slopes of Mount Meru is up to $2000 \mathrm{~mm}$ per year, while the northern slopes which are meant to be Leeward side receive rainfall between $500-600 \mathrm{~mm}$ per year (Kashenge,1986). The mean annual temperature is between 17 and $20{ }^{\circ} \mathrm{C}$ at lower altitudes. The soils are andosols on young volcanic stone (basalt lava) rich in nutrients and alkaline (soda); at higher altitudes, the soil is leached, forming acidic lithosols (Kashenge, 1986).

\section{Data Collection and Analysis}

A total of $24,15 \mathrm{~m} \mathrm{x} 15 \mathrm{~m}\left(225 \mathrm{~m}^{2}\right)$ plots as calculated from $n=\frac{\mathrm{CV}^{2} \mathrm{t}^{2}}{\mathrm{E}^{2}}$ were set at an interplot and transect distance of $350 \mathrm{~m}$. Since the vegetation of the study area was almost homogenous, systematic random sampling technique based on set transects and plots was performed, whereby the first plot was set randomly between $50-100 \mathrm{~m}$ from the forest edge, trailed systematically. The floristic diversity investigation was done as per methods 
used by Frontier-Tanzania (2004). Plot location was recorded using GPS for future monitoring. The collected data on plant species were on botanical names, their species abundance. All trees with a diameter breast height, at $1.3 \mathrm{~m}$ from ground $\geq 5 \mathrm{~cm}$ from both the canopy and sub-canopy layers, were recorded, counted and identified. The frequency of encounter of each species and its abundance was also counted and recorded. Regeneration plot within $2 \mathrm{~m}$ radius was laid out at the centre of $15 \mathrm{~m}$ radius plot to record, count and identified tree sapling, seedlings and non-woody plant species including grasses, herbs, sedges, ferns and shrubs. An observed plant species that were not recorded before in the plots were recorded. Plant species specimens were collected for further identification at the National Herbarium of Tanzania (NHT).

Shannon Wiener and Simpson indices were applied to calculate the diversity indices, while aboveground biomass and volume models were calculated using the biomass and volume models.

Computation of vegetation indices

\section{i. $\quad$ Diversity Indices}

Shannon Index of Diversity (H') and Simpson Index (ID):

$H^{\prime}=-$ Spilnpi (Kent, 2012) .............. [1]

$\mathrm{ID}=\mathrm{pi}^{2} .($ Kent, 2012) ................ [2]

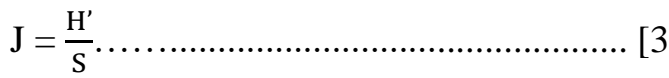

Family dominance \% (FD\%)

$\mathrm{D} \%=\frac{\mathrm{n} \sum \mathrm{nGE}}{\sum \mathrm{NGE}} \times 100 \%$

Quantification of biomass and carbon stocks

The allometric equations developed by Masota $e t$ al. (2016) for the montane forest with $\mathrm{DBH}$ and height as input parameters were used to estimate the individual tree aboveground biomass. Then, the biomass of each individual tree was converted into carbon in tons per hectare by multiplying biomass by 0.49 (percentage forest default value of aboveground carbon dry mass) (IPCC, 2006).

\section{ii. $\quad$ Allometric Models}

Above Ground Biomass (AGB):

$\mathrm{AGB}=0.9635 \times \mathrm{dbh}^{1.9440}$ (Masota et al., 2016) [5]

Tree Volume Model:

$\mathrm{Vm}^{3}=\mathrm{e}^{-7.41201}+2.1901527 \mathrm{x} \ln (\mathrm{dbh})($ Masota et al., 2016) [6]

\section{RESULTS AND DISCUSSION}

\section{Floristic Diversity of Nkoanenkole Catchment Forest Reserve (NCFR)}

It has been stated that the concept of plant species diversity includes two components: species richness and evenness. Species richness is the number of species per unit area while evenness is the abundance distribution of species in a community; also, there is a positive correlation between these indices; however, high species richness is not necessarily accompanied by highdegree evenness (Vasilevich, 2009). The study identified a total of 147 plant species from the 24 sample plots. Those plant species belonged to 56 families and 127 genera (Table 1). Out of the 147 plant species, 54 belonged to tree forms, while 93 were shrub, liana, sedge, herb, grass, and ferns (Table 2). The plant species diversity was facilitated by suitable habitat and reliable amount of rainfall supporting the growth of a variety of plants. Stevenson et al. (2012) supported that the distribution of plant sites is associated with ecological variables, among them being rainfall and temperature.

Table 1: Plant species families, genera, and species of Nkoanenkole Catchment Forest Reserve

\begin{tabular}{lll}
\hline Family Name & No. & Botanical name \\
\hline Acanthaceae & 1 & Barleria cristata \\
& 2 & Hypoestes aristata \\
& 3 & Hypoestes forskaolii \\
\hline
\end{tabular}


International Journal of Advanced Research, Volume 2, Issue 2, 2020

Article DOI: https://doi.org/10.37284/ijar.2.2.245

\begin{tabular}{|c|c|c|}
\hline Family Name & No. & Botanical name \\
\hline & 4 & Justicia flava \\
\hline & 5 & Microglossa pyrifolia \\
\hline Adiantaceae & 6 & Pellaea viridis \\
\hline Alangiaceae & 7 & Alangium chinense \\
\hline \multirow{3}{*}{ Amaranthaceae } & 8 & Achyranthes aspera \\
\hline & 9 & Cyathula cylindrica \\
\hline & 10 & Cyathula uncinulata \\
\hline \multirow[t]{5}{*}{ Apocynaceae } & 11 & Tabernaemontana ventricosa \\
\hline & 12 & Mondia whitei \\
\hline & 13 & Rauvolfia caffra \\
\hline & 14 & Pentarrhina abyssinicum \\
\hline & 15 & Secamone punctulata \\
\hline Araliaceae & 16 & Cussonia holstii \\
\hline Asparagaceae & 17 & Asparagus setaceus \\
\hline \multirow{2}{*}{ Aspleniaceae } & 18 & Asplenium strangeanum \\
\hline & 19 & Asplenium erectum \\
\hline \multirow[t]{9}{*}{ Asteraceae } & 20 & Ageratum conyzoides \\
\hline & 21 & Bidens pilosa \\
\hline & 22 & Conyza bonariensis \\
\hline & 23 & Montanoa hibiscifolia \\
\hline & 24 & Neonotonia wightii \\
\hline & 25 & Senecio syringifolia \\
\hline & 26 & Tithonia diversifolia \\
\hline & 27 & Vernonia sp \\
\hline & 28 & Vernonia galamensis \\
\hline \multirow[t]{2}{*}{ Boraginaceae } & 29 & Cordia africana \\
\hline & 30 & Ehretia cymosa \\
\hline \multirow[t]{2}{*}{ Capparaceae } & 31 & Ritchiea albersii \\
\hline & 32 & Capparis tomentosa \\
\hline Caricaceae & 33 & Carica papaya \\
\hline Celasteraceae & 34 & Salacia madagascariensis \\
\hline Commelinaceae & 35 & Commelina benghalensis \\
\hline \multirow[t]{2}{*}{ Convolvulaceae } & 36 & Cuscuta kilimanjari \\
\hline & 37 & Ipomoea wightii \\
\hline \multirow[t]{2}{*}{ Cucurbitaceae } & 38 & Momordica foetida \\
\hline & 39 & Zehneria scabra \\
\hline \multirow[t]{3}{*}{ Cyperaceae } & 40 & Carex chlorosaccus \\
\hline & 41 & Scleria muhlenbergiana \\
\hline & 42 & Scleria foliosa \\
\hline Dennstaedtiaceae & 43 & Blotiella glabra \\
\hline \multirow{3}{*}{$\begin{array}{l}\text { Dracaenaceae } \\
\text { Ebenaceae }\end{array}$} & 44 & Dracaena afromontana \\
\hline & 45 & Diospyros abyssinica \\
\hline & 46 & Euclea divinorum \\
\hline \multirow[t]{6}{*}{ Euphorbiaceae } & 47 & Bridelia micrantha \\
\hline & 48 & Croton macrostachyus \\
\hline & 49 & Croton sylvaticus \\
\hline & 50 & Neobotonia macrocalyx \\
\hline & 51 & Ricinus communis \\
\hline & 52 & Acalypha ornata \\
\hline
\end{tabular}


International Journal of Advanced Research, Volume 2, Issue 2, 2020

Article DOI: https://doi.org/10.37284/ijar.2.2.245

\begin{tabular}{|c|c|c|}
\hline Family Name & No. & Botanical name \\
\hline & 53 & Acalypha paniculata \\
\hline & 54 & Acalypha racemosa \\
\hline & 55 & Acalypha volkensii \\
\hline & 56 & Clutia abyssinica \\
\hline & 57 & Erythrococca fischeri \\
\hline & 58 & Phyllanthus ovalifolius \\
\hline & 59 & Tragia brevipes \\
\hline \multirow[t]{8}{*}{ Fabaceae } & 60 & Albizia gummifera \\
\hline & 61 & Amphicarpaea africana \\
\hline & 62 & Caesalpinia decapetala \\
\hline & 63 & Crotalaria axillaris \\
\hline & 64 & Dalbergia lactea \\
\hline & 65 & Desmodium repandum \\
\hline & 66 & Pterolobium stellatum \\
\hline & 67 & Senna semptilionalis \\
\hline \multirow[t]{3}{*}{ Flacourtiaceae } & 68 & Casearia battiscombei \\
\hline & 69 & Dovyalis abyssinica \\
\hline & 70 & Oncoba spinosa \\
\hline \multirow[t]{5}{*}{ Lamiaceae } & 71 & Hoslundia opposita \\
\hline & 72 & Leuca densiflora \\
\hline & 73 & Ocimum gratissimum \\
\hline & 74 & Clerodendrum johnstonii \\
\hline & 75 & Rotheca myricoides \\
\hline Loganiaceae & 76 & Strychnos henningsii \\
\hline \multirow[t]{3}{*}{ Malvaceae } & 77 & Abutilon longicuspe \\
\hline & 78 & Pavonia urens \\
\hline & 79 & Sida acuta \\
\hline \multirow[t]{4}{*}{ Meliaceae } & 80 & Ekebergia capensis \\
\hline & 81 & Trichilia emetica \\
\hline & 82 & Turraea holstii \\
\hline & 83 & Turraea robusta \\
\hline Melianthaceae & 84 & Bersama abyssinica \\
\hline Menispermaceae & 85 & Stephania abyssinica \\
\hline \multirow[t]{6}{*}{ Moraceae } & 86 & Ficus exasperata \\
\hline & 87 & Ficus ingens \\
\hline & 88 & Ficus lutea \\
\hline & 89 & Ficus sur \\
\hline & 90 & Ficus thonningii \\
\hline & 91 & Trilepesium madagascariensis \\
\hline Myrsinaceae & 92 & Embelia schimperi \\
\hline Myrtaceae & 93 & Syzygium guineense \\
\hline Oleaceae & 94 & Olea capensis \\
\hline Opiliaceae & 95 & Opilia amentacea \\
\hline \multirow[t]{2}{*}{ Oxalidaceae } & 96 & Oxalis corniculata \\
\hline & 97 & Oxalis latifolia \\
\hline Phytolaccaceae & 98 & Phytolacca dodecandra \\
\hline Piperaceae & 99 & Peperomia retusa \\
\hline \multirow[t]{2}{*}{ Poaceae } & 100 & Cynodon dactylon \\
\hline & 101 & Oplismenus compositus \\
\hline
\end{tabular}


International Journal of Advanced Research, Volume 2, Issue 2, 2020

Article DOI: https://doi.org/10.37284/ijar.2.2.245

\begin{tabular}{|c|c|c|}
\hline Family Name & No. & Botanical name \\
\hline & 102 & Panicum platycladum \\
\hline & 103 & Setaria giganteus \\
\hline \multirow[t]{2}{*}{ Polypodiaceae } & 104 & Drynaria rigidula \\
\hline & 105 & Pleopeltis excavata \\
\hline Pteridaceae & 106 & Pteris catoptera \\
\hline Ranunculaceae & 107 & Clematis simensis \\
\hline \multirow[t]{3}{*}{ Rhamnaceae } & 108 & Gouania longispicata \\
\hline & 109 & Helinus mystacinus \\
\hline & 110 & Scutia myrtina \\
\hline \multirow[t]{3}{*}{ Rosaceae } & 111 & Abrus precatorius \\
\hline & 112 & Fragaria vesca \\
\hline & 113 & Rubus pinnatus \\
\hline \multirow[t]{9}{*}{ Rubiaceae } & 114 & Coffea arabica \\
\hline & 115 & Lasianthus kilimandscharicus \\
\hline & 116 & Oxyanthus speciosus \\
\hline & 117 & Psychotria riparia \\
\hline & 118 & Rothmannia urcelliformis \\
\hline & 119 & Vangueria madagascariensis \\
\hline & 120 & Canthium uhligii \\
\hline & 121 & Pavetta sp. \\
\hline & 122 & Rubia cordifolia \\
\hline \multirow[t]{5}{*}{ Rutaceae } & 123 & Citrus lemon \\
\hline & 124 & Clausena anisata \\
\hline & 125 & Fagaropsis angolensis \\
\hline & 126 & Vepris simplicifolia \\
\hline & 127 & Toddalia asiatica \\
\hline \multirow[t]{3}{*}{ Sapindaceae } & 128 & Allophyllus abyssinica \\
\hline & 129 & Allophyllus africanus \\
\hline & 130 & Blighia unijugata \\
\hline Sapotaceae & 131 & Sapotaceae \\
\hline Simaroubaceae & 132 & Brucea antidycenterica \\
\hline Smilacaceae & 133 & Smilax kraussiana \\
\hline \multirow[t]{3}{*}{ Solanaceae } & 134 & Solanum aculeatissimum \\
\hline & 135 & Solanum anguivi \\
\hline & 136 & Solanum terminale \\
\hline Sterculiaceae & 137 & Dombeya kirkii \\
\hline Thymeliaceae & 138 & Peddiea fischeri \\
\hline \multirow[t]{2}{*}{ Tiliaceae } & 139 & Grewia similis \\
\hline & 140 & Triumfetta rhomboidea \\
\hline \multirow[t]{3}{*}{ Ulmaceae } & 141 & Celtis africana \\
\hline & 142 & Chaetacme aristata \\
\hline & 143 & Trema orientalis \\
\hline Urticaceae & 144 & Girardinia diversifolia \\
\hline \multirow[t]{2}{*}{ Vitaceae } & 145 & Ampelocissus africana \\
\hline & 146 & Cyphostemma adenocaule \\
\hline
\end{tabular}

According to their growth forms, 54 were trees, 31 included shrubs and lianas, 48 were herbs, 3 were sedges, 6 were grasses, and 6 belonged to the ferns
(Table 2). The computations revealed high plant species diversity as a rule that the higher the H' the higher the diversity and the vice versa is true, while 
the lower the ID, the higher the diversity and the vice versa is true in the scale of 0 to 1 . From the survey findings it has been noted that due to presence of high diversity of vegetation categories classified from the study area, there is also a high diversity of species as well as life forms (Table 1). The survey identified a total of 147 plant species. The largest species composition was from trees $(36.73 \%)$ trailed by herbs $(31.97 \%)$, shrubs including lianas (21.09\%), grasses and sedges (4.08\% each), and sedges were ranked the least (2.04\%). . (Table 2).

Table 2: Total number of plant species per growth form category

\begin{tabular}{lll}
\hline Growth form & Total species & \% \\
\hline Trees & 54 & 36.73 \\
Shrubs \& lianas & 31 & 21.09 \\
Sedges & 3 & 2.04 \\
Grasses & 6 & 4.08
\end{tabular}

\begin{tabular}{lll}
\hline Growth form & Total species & \% \\
\hline Ferns & 6 & 4.08 \\
Herbs & 47 & 31.97 \\
\hline Total & $\mathbf{1 4 7}$ & $\mathbf{1 0 0}$ \\
\hline
\end{tabular}

\section{Floristic Species Density (H') and Dominance}

The identified tree species had a density of 306.086 while the other forms got a density of 1459.071, with the $\mathrm{H}^{\prime}$ of 3.3316 for trees and 2.44911 for other growth forms (Table 3). Both trees and other growth forms were not evenly distributed (Table 3) with a $\mathrm{J}$ of 0.84 and reciprocal (R) of 18.87 for trees and $0.54(\mathrm{~J})$ and $3.19(\mathrm{R})$ for shrubs, herbs, sedges, grasses and ferns. The unevenness results meant there was unequal abundance of the identified and counted plant species from the sample plots. Verberk (2011) reported that the variation in the number of stems of the plant species lead to the unevenness of plant species distribution as it depends on the number of stems of the plants.

Table 3: Plant species density, Shannon Wiever (H'), and Simpson indices, evenness, and reciprocal

\begin{tabular}{llllll}
\hline Growth category & Density & H' & ID & J & R \\
\hline Trees & 306.086 & 3.33 & 0.05 & 0.84 & 18.87 \\
Sr,Hb,Gr, Sg, Fn & 1459.71 & 2.45 & 0.31 & 0.54 & 3.19 \\
\hline Key: J=evenness; $R=$ recirprocal; Sr = shrub; Hb=herb; Gr=grass; Sg=sedge; Fn=fern &
\end{tabular}

The most dominant trees were $T$. ventricosa, $E$. divinorum, D. abyssinica, C. anisata, B. unijugata, $B$. abyssinica, C. africana, $C$. sylicaticus and $C$. africana. While A. aspera, O. compositus, $T$. brevipes, Setaria sp., T. diversifolia and S. foliosa were among dominant plants form the other growth forms (shrubs, herbs, grasses and sedges) (Table 2). Ifo et al. (2016) conducted a study in the tropical forests of Congo revealed that those trees species with the largest number of stems were the most dominant.

\section{Plant families of Nkoanennkole Catchment Forest Reserve (NCFR)}

The most dominant families got the highest number of genera and species of all others. The most dominant families were; Euphorbiaceae with $7.087 \%$ for genera and $8.844 \%$ for species; Rubiaceae $(7.08 \%$ for genera and $6.122 \%$ for species); Fabaceae (6.299\% for genera and 5.442 for species); Asteraceae with $6.299 \%$ for genera and $6.122 \%$ for species (Figure 2). 
Figure 2: Family species dominance based on the number of genera and species percentages

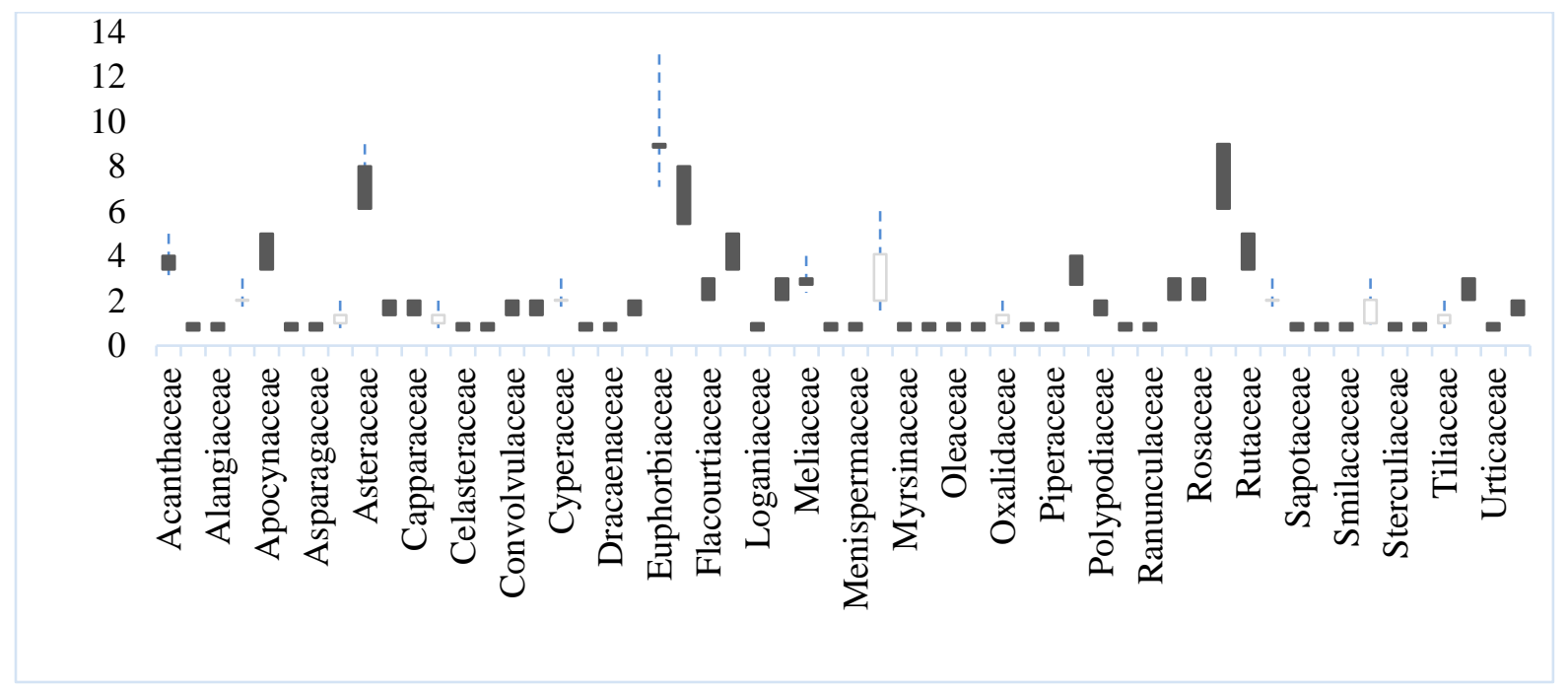

Tree Species Seedlings Density and Relative Density

The sustainability of the vegetation cover is grounded on the successive stages of plant growth from seed bank germination, seedling, sapling, poles and finally a mature tree. The survey identified 14 tree species seedlings (Table 4). This indicated the NCFR sustainability, as the mature trees will die, they are replaced by the poles, while poles will be replaced by the saplings and the saplings will be replaced by the seedlings. Of all tree seedlings, $P$. riparia was the highest in terms of density per hectare (16.51), B. abyssinica (11.795), C. africana (10.026), V. simplicifolia (9.436), D. abyssinica (7.667), S. guineense and $T$. ventricosa (5.898), while the rest got a density of less than 5 (Table 4).

Table 4: Tree species seedlings density and relative density

\begin{tabular}{llll}
\hline Scientific Name & Abundance & Density & Relative Density \\
\hline Allophyllus africanus & 5 & 2.949 & 3.60 \\
Bersama abyssinica & 20 & 11.795 & 14.39 \\
Blighia unijugata & 4 & 2.359 & 2.88 \\
Celtis africana & 17 & 10.026 & 12.23 \\
Coffea arabica & 2 & 1.180 & 1.44 \\
Diospyros abyssinica & 13 & 7.667 & 9.35 \\
Peddiea fischeri & 3 & 1.769 & 2.16 \\
Psychotria riparia & 28 & 16.513 & 20.14 \\
Ritchiea albersii & 1 & 0.590 & 0.72 \\
Syzygium guineense & 10 & 5.898 & 7.19 \\
Tabernaemontana ventricosa & 10 & 5.898 & 7.19 \\
Trichilia emetica & 8 & 4.718 & 5.76 \\
Turraea robusta & 2 & 1.180 & 1.44 \\
Vepris simplicifolia & 16 & 9.436 & 11.51 \\
\hline Total & $\mathbf{1 3 9}$ & $\mathbf{8 1 . 9 8}$ & $\mathbf{1 0 0}$ \\
\hline
\end{tabular}


Tree Species Aboveground Biomass and Carbon Stocks per Diameter Class

The study revealed that those classes with large basal area per hectare also had larger biomass per hectare. The AGB ranged from $68.22 \pm 3.32$ (Figure 3), with AGC mg ha- ${ }^{1}$ of $57.835 \pm 2.815$ (Figure 3). The DBH-class of $15 \pm 5$ was revealed to have the highest AGBkg/Ha and AGC mg ha ${ }^{-1}$, trailed by DBH-class $25 \pm 15,55 \pm 45,65 \pm 55$, $35 \pm 25$ and others (Figure 3 ). The highest AGB and AGC for the DBH-class $15 \pm 5$ was facilitated by the number of stems measured from the sample plots (Figure 3), while the least, from DBH-class
$>115$ and $115 \pm 105$ (Figure 3), was due to the least number of stems measured from the sample plots. This entailed few old trees than the younger trees that were going to take off in the future, and hence forest future sustainability. The larger the diameter, the larger the AGB and AGC, and the vice versa is true. Dean (2004); Balderas Torres and Lovett (2013) highlighted that there is a linear relationship between the standing tree diameter or basal area and above-ground biomass. Also, Shirima et al. (2014) highlighted that there is a relationship between plant species richness, evenness and aboveground biomass and carbon.

\section{Figure 3: Aboveground Biomass (AGB) for NCFR}

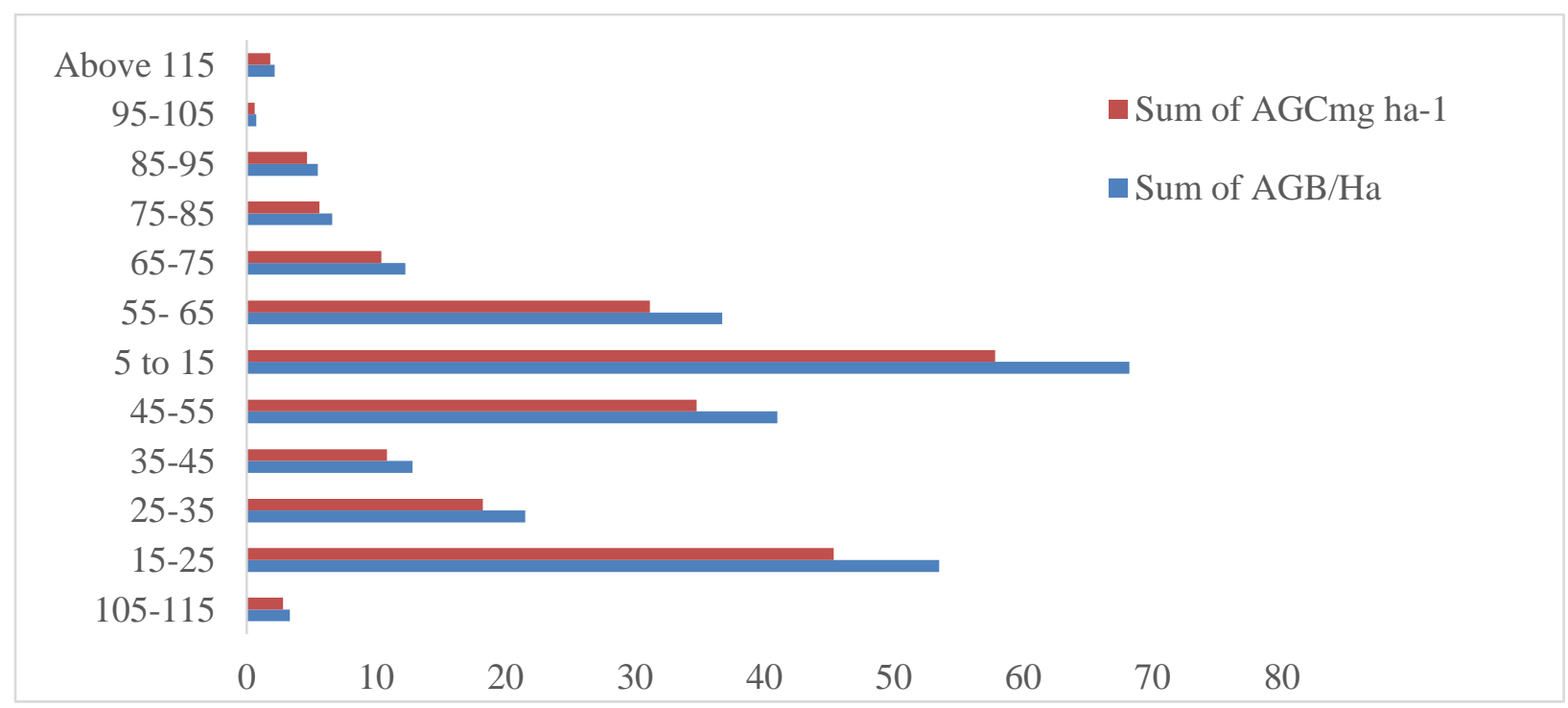

\section{Forest Stocking with Respect to Diameter Classes}

The estimation of the number of trees per acre or hectare is one way of determining the tree stocks, while others are basal area as calculated from measured DBH, and volume (Martin, 1986). The study found that there was a decrease in the number of stems from low-class diameter to high-class diameter, an implication that there was a sort of harvesting of trees with a larger diameter. On the other hand, this is a case in a natural forest where there tend to be active regeneration and a mixture of trees of various age classes. Initially, some years back there had been severe harvesting of larger trees for timber, and even recently, there had been rare poaching for the same too. The large diameter tree species found in NCFR entail the serious protection by TFS. The DBH class of $75-\geq 115 \mathrm{~cm}$ showed the lowest stocking, and this can be assumed being resulted from overexploitation, as this class could suite the human consumption interest for timber, and other needs requiring large boles. 
Figure 4: Number of stems per hectare of standing tree diameter by classes at NCFR

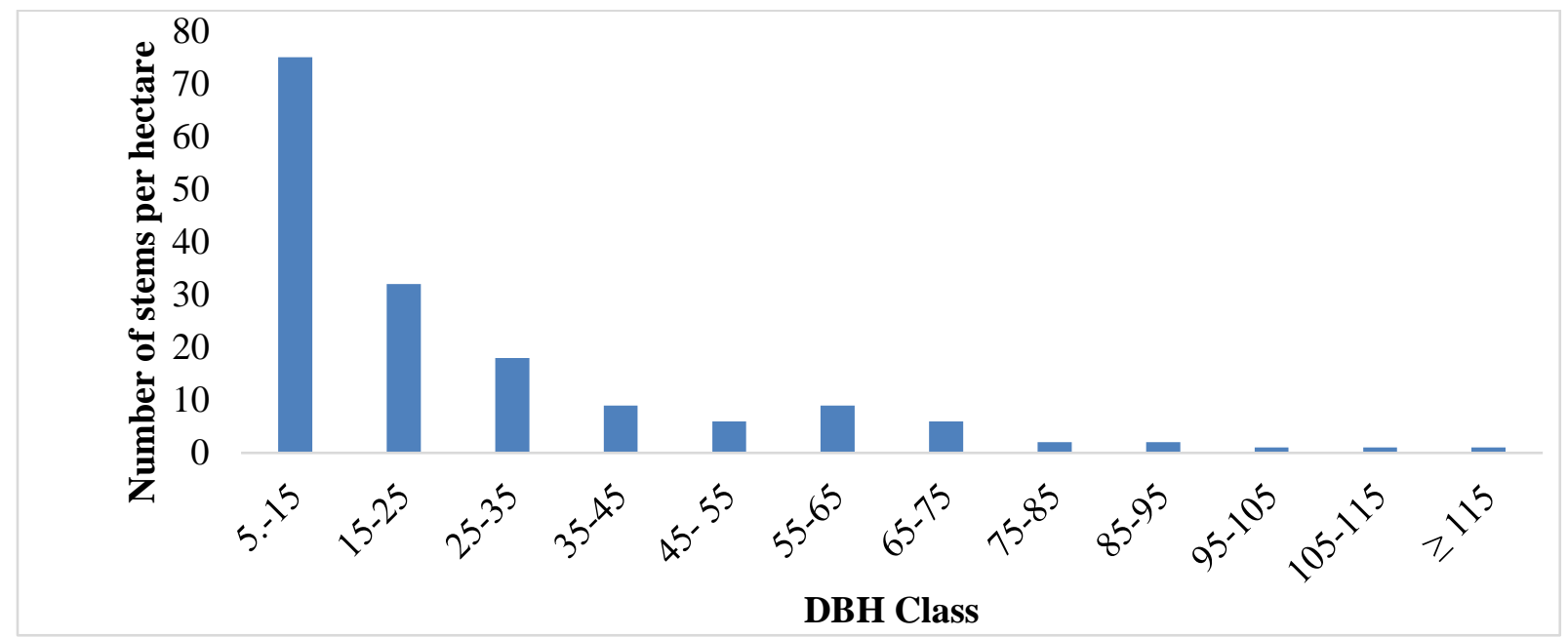

\section{CONCLUSION}

Nkoanenkole Catchment Forest Reserve has been revealed to contain high floristic diversitysupporting the water catchment areas for the benefit of bordering community, carbon sinks, rainfall and temperature regulation, windbreak and as wildlife habit for wildlife. Further studies on biological species are needed, upgrading the nature reserve, forest conservation education and awareness creation to the local community by the Tanzania Forest Service (TFS) is needed.

\section{ACKNOWLEDGEMENT}

The Arumeru District officials and community stakeholders consulted for their efforts and assistance in the course of data and information collection. The survey team wishes to acknowledge the District Game Officers (GO), Forest Manager (FM), Environmentalist, Village Natural Resources Committees (VNRCs), Village Leaders including chairpersons, village executive secretaries, community members who offered support accordingly during data collection.

\section{REFERENCES}

Asner, G. P., Brodrick, P. G., Philipson, C., Vaughn, N. R., Martin, R. E., Knapp, D. E., ... \& Stark, D. J. (2018). Mapped aboveground carbon stocks to advance forest conservation and recovery in Malaysian Borneo. Biological Conservation, 217, 289-310.
Balderas Torres, A., \& Lovett, J. C. (2013). Using basal area to estimate aboveground carbon stocks in forests: La Primavera Biosphere's Reserve, Mexico. Forestry, 86(2), 267-281.

Dean, T. J. (2004). Basal area increment and growth efficiency as functions of canopy dynamics and stem mechanics. Forest Science, 50(1), 106116.

FAO. (2011). Forests are key for high-quality water supply. Better forest management needed to maximize water-related benefits from forests. Food and Agriculture Organization of the United Nations.

Forbes, K., \& Broadhead, J. (2013). Forests and landslides: The role of trees and forests in the prevention of landslides and rehabilitation of landslide-affected areas in Asia. Rap Publication, No. 2013/02. Bangok, Thailand: FAO Regional Office for Asia and the Pacific.

Funmilayo, O. A. (2014). The place of forest and ecotourism in the economic development of Nigeria. International Journal of Technical Research and Applications, 2(7), 17-21.

Ifo, S. A., Moutsambote, J. M., Koubouana, F., Yoka, J., Ndzai, S. F., Bouetou-Kadilamio, L. N. O., .. \& Mbemba, M. (2016). Tree species diversity, richness, and similarity in intact and degraded forest in the tropical rainforest of the Congo Basin: case of the forest of Likouala in 
the Republic of Congo. International Journal of Forestry Research, 2016.

Kara, F. (2018). A silvicultural management tool for the Oriental beech (Fagus orientalis Lipsky) forests. Journal of Sustainable Forestry, 37(4), 403-413.

Kashenge, S. S. (1986). Management Plan for Catchment Forests, Arusha Region. Ministry of Natural Resources and Tourism, Tanzania. Forest Division, Catchment.

Kayombo, C. J., Giliba, R. A., Mgumia, F., \& Kashindye, A. (2017). Assessment of anthropogenic activities, tree species composition and diversity at Nkoanenkole Catchment Forest Reserve in Arumeru District. Proceedings of the eleventh TAWIRI Scientific Conference, 6th -8 th December 2017, (Pp. 235-240). Arusha International Conference Center, Tanzania.

Kent, M. (2012). Vegetation description and data analysis: a practical approach ( $2^{\text {nd }}$ edition). John Wiley \& Sons.

Martin, J. (1986). Wisconsin woodlands: Estimating stocking conditions in your timber stand. University of Wisconsin, Cooperative Extension Service (USA).

Masota, A. M., Bollandsås, O. M., Zahabu, E., \& Eid, T. (2016). Chapter 4: Allometric Biomass and Volume Models for Lowland and Humid Montane Forests. In Malimbwi, R. E., Eid T., \& Chamshama, S. A. O. (Ed), Allometric Tree Biomass and Volume Models in Tanzania, 35. Morogoro, TZ: Department of Forest Mensuration and Management, Sokoine University of Agriculture.

Ministry of Natural Resources and Tourism (MNRT). (1998). National Forest Policy. Dar es Salaam, United Republic of Tanzania: Government Printer.

MNRT. (1998). National Forest Policy. Ministry of Natural Resources and Tourism, Dar es Salaam, pp 59.

National Research Council. (2010). Advancing the Science of Climate Change. America's Climate
Choice. Panel on Advancing the Science of Climate change. Washington DC: Division on Earth and Life Studies. National Research Council of the National Academies. The National Academic Press.

Shirima, D. D., Totland, Ø., Munishi, P. K., \& Moe, S. R. (2015). Relationships between tree species richness, evenness and aboveground carbon storage in montane forests and miombo woodlands of Tanzania. Basic and Applied Ecology, 16(3), 239-249.

Stevenson, P. R., Castellanos, M. C., \& Agudelo, J. (2012). Patterns of plant species richness within families and genera in lowland neotropical forests: Are similarities related to ecological factors or to chance? Tropical forests, 71-92.

URT. (2002). The National Water Policy. Dar es Salaam: United Republic of Tanzania (URT): Government Printer.

URT. (2009). Fourth National Report on Implementation of Convention on Biological Diversity (CBD). Dar es Salaam: Division of Environment, Vice President's Office, United Republic of Tanzania.

Vasilevich, V. I. (2009). Species diversity of plants. Contemporary problems of ecology, 2(4), 297303.

Verberk, W. C. E. P. (2011). Explaining general patterns in species abundance and distributions. Nature Education Knowledge, 3(10), 38. 